DOI: 10.1515/auseur-2016-0016

\title{
Name Geography beyond Borders
}

\author{
A Review of the Volume Ferenc Vörös (ed.) From \\ Linguistic Geography to Name Geography ${ }^{1}$
}

\section{Barna BODÓ}

Sapientia University, Cluj-Napoca

The meaning of special terms like linguistic geography and name geography might be obvious for linguists, but for the representatives of other scientific branches it is perhaps necessary to present in the introduction the definition of these two terms.

For linguists, linguistic geography is above all a way of approach and a research method. They are searching the answers - through the methods of linguistic geography - for some questions beyond general linguistics and linguistics in general. There are three main dimensions of the language: spatial, social, and time-related dimensions. Linguistic geography analyses the spatial dimension of language, respectively it approaches to social and time-related dimensions from the viewpoint of the former. Linguistic geography is a branch of linguistics dealing with the geographic distribution of languages; it can also be called Geolinguistics, and thus it can be regarded as spatial linguistics - yet, these two terms cannot be conceived as perfect synonyms. Linguistic geography deals with the problematic of language contacts (another term used for this is areal linguistics), and it also focuses on the study of different dialects and language variants. Linguistic geography presents the variants of a certain language in space, it elaborates maps regarding the linguistics phenomena, and, accepting the principle of spatial connections, it tries to draw linguistic and extralinguistic conclusions.

Linguistic geography - as a special term - is a calque similar to the German word Sprachgeographie. Both concepts refer to the geographical study of language. Linguistic geography is a more recent term than geolinguistics, a word of Greek-Latin origin used in contactology.

This field looks back on a rich tradition, it tries to draw historical and sociological conclusions based on the territorial aspects of proper names. In spite

1 Ferenc Vörös (ed.) A nyelvföldrajztól a névföldrajzig, UMIZ - Imre Samu Nyelvi Intézet, Unterwart/Alsóőr - Budapest 2015. 
of the fact that the most important researches of the domain deal mainly with the early Hungarian toponyms and hydronyms, due to the growing quantity of data the analysis of micro-names becomes more and more important. Thus, we arrive at the field of name geography.

Scholarly literature dealing with name geography used the databases containing geographical names to define dialects and to make researches regarding the history of language and the history of dialects due to the fact that these were very well-localized linguistic data. Some of the researchers dealing with toponyms present from a geographical viewpoint the systematic features of naming and the inner characteristics of proper names (all these are relevant for the study of the formation of Hungarian toponyms). Newer data collection provides scholars with a large quantity of data containing proper names. These researches rose the possibility of mapping the spatial dimensions of naming similarly to the mapping of dialects.

The volume edited by Ferenc Vörös (From Linguistic Geography to Name Geography VI. - Name Geography beyond Borders, UMIZ - Imre Samu Nyelvi Intézet, Unterwart/Alsóőr - Budapest 2015) is the volume of the proceedings of a Conference organized at Unterwart in May 2015. It was published by the Imre Samu Linguistic Institute.

First of all, it is interesting that in a small locality of Burgenland, Austria there exists a linguistic institute functioning at the Hungarian Media and Information Centre in Unterwart/Alsóőr (UMIZ). We might wonder why this Institute functions in a small locality when the majority of research institutes exist in big cities. The answer to the former question lies in the fact that the research network called Termini, which expands to the whole Carpathian Basin, considers it important to have a research institute in all the countries having Hungarian minority.

The volume includes 11 studies geographically embracing Western Hungary and Burgenland, Subcarpathia, Moldavian Changos, Baranya, South-Hungary, Voivodina, Great Britain, Alto Adige, and South Tyrol. A study dealing with surnames and the typology of contact phenomenon must be mentioned as well due to its international character.

This is an article written by Attila Benő, István Lanstyák, and Ferenc Vörös and is entitled The Typology of Language Contact Phenomena: the Case of Surnames, focusing on Hungarian surnames and the typology of the language contact phenomena occurring in the case of surnames. In their analysis, the authors present direct and indirect effects and structural elements. Their data refer to Hungary as well, but they take into consideration the other regions of the Carpathian Basin having Hungarian inhabitants too. Their study presents the most important etymological issues regarding surnames borrowed from other languages and it enumerates the ways of their accommodation to the structure of the receiving language. 
Tamás Farkas elaborated an article with the title Surname and Ethnicity: Ways and Possibilities in Hungarian and International Applied Onomastic Research, which deals with the ethnic etiquetting feature of proper names and it shows the interdisciplinary character of the study of toponyms. The first part of the article presents the role of synchronic study of toponyms in the reconstruction of ethnicity and it underlines the connections of proper names with ethnical identity. The most important part of the article presents the practical role of these researches, pointing out some issues for which these works can provide a theoretical background. Thus, marketing, public health, and genetics are mentioned in the article, accentuating the potential social advantages and disadvantages.

Another important article of the volume is entitled Ince János Petrás's Registers of Family Names in the $19^{\text {th }}$-Century Moldavia. The Surnames of Somoska and it is written by Vilmos Tánczos. This study - based on the documents existing in the Archive - presents the data included in the folklore collection of a priest in Cleja, elaborated between 1855 and 1876 and containing data regarding 14 villages in which he made a census of the families living there. The second part of the study compares the historical resources with the names actually used and officially registered in Somoska, a Moldavian Chango village. Another important aspect is that the researches dealing with surnames are important not only for toponymy but for cultural anthropology as well. A Moldavian Chango often asks the interviewer: Shall I tell my Romanian or my Chango name? In some cases, there is a great discrepancy between the two variants.

Ferenc Vörös in his study Surnames in Western Hungary and Burgenland from the Perspective of Historical Surname Geography (the first article of the volume) relies on a database collected during a national census in 1720 . He defines six lexical and three morpho-semantic categories; in the cartograms, we may find both surnames used at national level and surnames used only in some regions. The cartograms offer supplementary data for the study of ethnic composition of western borderline and for the better definition of the language borders.

We do not have the possibility to present in a detailed manner all the articles, and thus we have decided to present one more study. This study is entitled Family Names and Bilingualism in the Cemeteries of Burgenland and was written by Szilvia Szoták. The author studies the epitaphs that can be found in the cemeteries of Burgenland. The epitaphs are used as a visual cartogram of proper names, and according to this map the author concluded that the Hungarian population of Burgenland was bilingual. The epitaphs offer information regarding the language composition of the population, the statute of the different languages, and the linguistic vitality of the local communities. The research shows that the number of German epitaphs grows even amongst Hungarian families. This shows that the local Hungarian population reached the last phase of language shift. The generation that used Hungarian is dying. 
The volume is characterized by permanence, it is strongly related to the topic of the former conferences: surnames, toponyms, issues regarding national minorities. Some of the studies deal with interethnic relations as well. A very important aspect of the volume is that it embraces a large geographical region: it has some articles dealing with international topics as well and some focusing on the historical Hungarian regions. The volume and the conference are connected to the larger project dealing with the elaboration of the Hungarian Surname Atlas.

The volume is an interesting and useful book not only for linguists and anthropologists but for all the people somehow interested in the problematics of the Hungarians living in the Carpathian Basin. 